Jurnal Keperawatan Silampari

Volume 4, Nomor 1, Desember 2020

e-ISSN: 2581-1975

p-ISSN: 2597-7482

DOI: https://doi.org/10.31539/jks.v4i1.1514

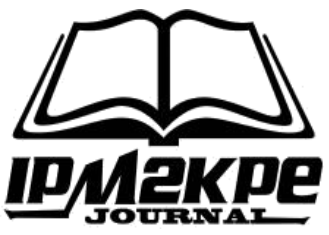

\title{
SPIRITUAL EMOTIONAL FREEDOM TECHNIQUE (SEFT) TERHADAP KUALITAS HIDUP PASIEN HIV/AIDS
}

\author{
Defia Roza ${ }^{1}$, Sila Dewi Anggreni ${ }^{2}$, Heppi Sasmita $^{3}$, Yessi Fadriyanti ${ }^{4}$, Nova Yanti ${ }^{5}$ \\ Politeknik Kesehatan Kementerian Kesehatan Padang 1,2,3,4,5 \\ defiaroza@rocketmail.com ${ }^{1}$
}

\begin{abstract}
ABSTRAK
Tujuan dari penelitian ini untuk mengetahui efektifitas intervensi SEFT terhadap peningkatan kualitas hidup pasien HIV/AIDS di Kota Padang. Desain penelitian ini adalah Quasi eksperimen dengan rancangan one group pretest and posttest. Hasil penelitian ini didapatkan bahwa rata rata kualitas hidup pasien HIV sebelum pemberian SEFT adalah 97,07 dan rata rata kualitas hidup pasien HIV sesudah pemberian SEFT adalah 102,6. Terlihat nilai mean perbedaan antara sebelum dan sesudah tindakan SEFT adalah 5,57 dengan standar deviasi 6,98. Hasil Uji statistic didapatkan nilai $\mathrm{p}=0,011$. Simpulan, ada perbedaan yang signifikan antara kualitas hidup pasien HIV sebelum dan sesudah tindakan SEFT.
\end{abstract}

Kata Kunci : HIV, Kualitas Hidup, SEFT

\section{ABSTRACT}

This study aimed to determine the effectiveness of SEFT interventions in improving the quality of life of HIV / AIDS patients in Padang City. The design of this study was a Quasi-experimental design with one group pretest and posttest. This study found that the average quality of life of HIV patients before SEFT administration was 97.07, and the average rate of life of HIV patients after SEFT administration was 102.6. It can be seen that the mean difference between before and after SEFT action is 5.57 with a standard deviation of 6.98. The statistical test results obtained $p$-value $=0.011$. In conclusion, there is a significant difference between the quality of life of HIV patients before and after SEFT treatment.

Keywords: HIV, Quality of Life, SEFT

\section{PENDAHULUAN}

HIV AIDS adalah penyakit yang menimbulkan banyak masalah baik fisik maupun psikis . Pasien HIV/AIDS, akan mengalami kondisi psikis yang berat ketika mereka menerima vonis terkena HIV/AIDS. Rasa malu, takut adanya penolakan dan stigma bahwa penyakit HIV berasal dari perilaku yang buruk, membuat seseorang yang terkena penyakit tersebut merasa terasing dan menimbulkan dampak psikologi yang hebat (Blanco et al., 2020). Pasien HIV sering mengalami depresi. Depresi yang tidak tertanggulangi dengan baik dapat menurunkan sistim imunitas penderita HIV, sehingga menyebabkan kualitas hidup pasien HIV menjadi menurun (Andri et al., 2020). 
Salah satu intervensi yang bisa dilakukan untuk meningkatkan kualitas hidup pasien HIV adalah tindakan spiritual emotional Freedom Tekhnique (SEFT). SEFT merupakan gabungan antara spiritual therapy dengan emotional Freedom Teknique (EFT). SEFT merupakan salah satu terapi komplementer yang dapat digunakan untuk menurunkan ganguan Psikologis. Keefektifan SEFT terletak pada pengabungan antara Spiritual Power dengan Energy Psychology. Spiritual Power memiliki lima prinsip utama yaitu ikhlas, yakin, syukur, sabar dan khusyu. Ketidakseimbangan kimia dan gangguan energi dalam tubuh manusia dapat menyebabkan gangguan emosi, termasuk depresi. Intervensi SEFT pada sistim energi tubuh inilah yang dapat mengubah kondisi kimia di dalam otak (neurotransmitter) yang selanjutnya dapat mengubah kondisi emosi seseorang.

Terapi Spiritual Emotional Freedom Technique (SEFT) merupakan teknik yang memiliki tujuan untuk mengembangkan kemampuan individu dalam penyembuhan dirinya. Teknik ini dapat digunakan untuk melatih individu memahami bahwa energi psikis mereka berupa perasaan, pikiran, dan emosi berperan dalam setiap pengalaman. Sehingga ketika seseorang yang percaya bahwa dirinya tidak mampu, maka hal itu akan menghalangi dirinya dalam menggunakan kemampuan yang sesungguhnya ada. Teknik SEFT dapat membantu melatih pasien HIV AIDS memahami dan menerima keadaan diri mereka sendiri,selain itu dapat melatih untuk menyadar isi sinegatif dalamdirinya dan mengetahui untuk hidup bahagia dengan sisi negative yang dimiliki, serta menjadikan pengalaman negatifnya menjadi pelajaran positif dalam hidupnya.

Beberapa penelitian telah mengungkapkan bahwa SEFT sangat baik dilakukan untuk mengatasi masalah psikologis pasien. Penelitian Bach et al., (2019). menjelaskan bahwa tindakan EFT menyebabkan penurunan kecemasan, depresi, gangguan stress pasca trauma. Penelitian Vural (2019) menyimpulkan bahwa EFT sangat membantu dalam menurunkan kecemasan melahirkan. Penelitian Stapleton et al., (2018) didapatkan hasil EFT dapat menurunkan aktivitas otak daerah limbik dan mengurangi gejala terkait makanan pada individu yang kelebihan berat badan / obesitas. Studi ini juga menjelaskan mekanisme neurologis yang bekerja di balik banyak hasil studi EFT yang berhasil untuk menurunkan berat badan. Penelitian Nicosia e al., (2019) didapatkan bahwa intervensi EFT efektif untuk mengobati Post Traumatic Stress Disorder (PTSD).

Penelitian Ardan (2020) didapatkan hasil bahwa terapi SEFT untuk dapat mengontrol tingkat depresi pada orang dengan HIV AIDS (ODHA) secara non farmakologis. Penelitian Dewi \& Fitri (2020) menyimpulkan bahwa SEFT dapat mngurangi kecemasan dan depresi pada saat rehabilitasi pecandu napza. Penelitian Nurbani \& Yuniar (2020) dapat diketahui bahwa SEFT dapat mengurang depresi pada pasien Diabetes Mellitus. Penelitian Aminuddin et al., (2019) menunjukkan bahwa SEFT dapat menurunkan intensitas kebiasaan merokok masyarakat.

Walaupun penelitian tentang SEFT ini sudah banyak dilakukan, tetapi penelitian tentang keefektifan SEFT untuk meningkatkan kualitas hidup pasien HIV belum ada. Oleh karena itu hasil penelitian ini dapat dapat dimanfaatkan oleh pasien HIV/AIDS untuk meningkatkan kualitas hidupnya.

\section{METODE PENELITIAN}

Disain penelitian ini adalah Quasi eksperimen dan rancangan yang digunakan yaitu one group pretest and posttest.Penelitian dilaksanakan di Yayasan Taratak Jiwa hati Padang. Waktu penelitian dimulai bulan April sampai November 2019. Populasi adalah seluruh pasien HIV AIDS yang terdaftar di yayasan Taratak Jiwa Hati Padang dan yang menjadi sampel penelitian ini sebanyak 14 orang . 
Tekhnik pengambilan sampel yang digunakan adalah purposive sampling dengan kriteria inklusi sampelnya adalah: pasien yang berusia 30-65 tahun, pasien bersedia menandatangani informed consent,dapat memahami komunikasi dengan baik. Kriteria eksklusi pada penelitian ini adalah pasien memiliki riwayat depresi Berat, pasien mengalami gejala infeksi oportunistik yang berat.

Pelaksanaan penelitian ini dimulai dengan memberikan pelatihan kepada responden tentang cara melakukan Spiritual Emotional Freedom Technique dengan nara sumber yang pakar tentang SEFT. Dan pada saat itu dilakukan pengisian kuesioner tentang Kualitas Hidup yang dimodifikasi dari WHOQOL- BREF yang terdiri dari 31 item pertanyaan dan responden diberikan modul tindakan tersebut, sehingga sangat membantu pasien untuk melaksanakan tindakan tersebut jika lupa. Responden melakukan tindakan SEFT 2 kali sehari yaitu pada saat selesai magrib dan setelah shalat subuh, dan responden melaporkan pelaksanaan intervensi setiap harinya, melalui telepon dan whatsapp. Responden juga melaporkan kendala kendala yang dialami selama penelitian, sehingga peneliti bisa membantu mengatasinya.Setelah 7 hari pelaksanaan SEFT, responden diminta mengisi kuesioner kualitas hidup kembali ( postest).

Data yang telah diperoleh dianalisa secara statistik dengan menggunakan komputerisasi dengan menggunakan uji Paired t test karena data terdistribusi normal dengan tingkat kemaknaan $95 \%(\mathrm{p} \leq 0,05)$

\section{HASIL PENELITIAN}

Karakteristik Responden

Tabel. 1

Karakteristik Responden

\begin{tabular}{|c|c|c|c|}
\hline Variabel & Kategori & Frekwensi & Persentase \\
\hline \multirow{2}{*}{ Jenis Kelamin } & Laki laki & 11 & 78 \\
\hline & Perempuan & 3 & 22 \\
\hline \multirow{4}{*}{ Pekerjaan } & Wiraswasta & 10 & $\overline{71,4}$ \\
\hline & Rumah Tangga & 2 & 14,3 \\
\hline & Karyawan swasta & 1 & 7,14 \\
\hline & Guru Swasta & 1 & 7,14 \\
\hline \multirow[t]{3}{*}{ Pendidikan } & SMA & 11 & 78,5 \\
\hline & Diploma 1 & 1 & 7,1 \\
\hline & Sarjana & 2 & 14,3 \\
\hline \multirow[t]{4}{*}{ Status Kesehatan } & Sangat baik & 1 & 7,1 \\
\hline & Baik baik Saja & 9 & 64,3 \\
\hline & Biasa saja & 1 & 7,1 \\
\hline & Buruk & 3 & 21,4 \\
\hline Status & Kawin & 7 & 50 \\
\hline Perkawinan & Belum Kawin & 7 & 50 \\
\hline \multirow[t]{3}{*}{ Status HIV } & Tidak Bergejala & 7 & 50 \\
\hline & Bergejala & 5 & 35,7 \\
\hline & Sudah AIDS & 2 & 14,3 \\
\hline Faktor $\quad$ Resiko & LSL & 9 & 64,3 \\
\hline \multirow[t]{2}{*}{ Penularan HIV } & Penggunaan Narkoba Suntik & 4 & 28,6 \\
\hline & Tertular dari Suami & 1 & 7,1 \\
\hline
\end{tabular}

Berdasarkan tabel 1 mayoritas responden adalah laki-laki yaitu sebanyak 11 (78\%) responden dengan pekerjaan wiraswasta sebanyak $10(71,4 \%)$. Mayoritas status pendidikan adalah SMA sebanyak $11(78,5 \%)$ responden dengan status kesehatan 
sebagian besar baik-baik saja sebanyak 9 (64,3\%). Status menikah seimbang antara responden yang kawin dan belum kawin yaitu masing-masing 50\%, faktor resiko penularan HIV sebagian besar melalui LSL yaitu sebanyak $9(64,3 \%)$ responden.

\section{Analisa Univariat}

Tabel. 2

Distribusi Skort Kualitas Hidup Pasien HIV Sebelum Pelaksanaan SEFT

\begin{tabular}{ll}
\hline Skort Kualitas Hidup & Nilai \\
\hline Mean & 97,07 \\
SD & 10,292 \\
Minimal-maksimal & $83-116$ \\
95\% CI & $91,13-103,01$ \\
\hline
\end{tabular}

Berdasarkan tabel 2 didapatkan bahwa rata rata kualitas hidup pasien HIV sebelum pemberian SEFT adalah 97,07 dengan standar deviasi 10,092.

Tabel. 3

Distribusi Skort Kualitas Hidup Pasien HIV Sesudah Pelaksanaan SEFT

\begin{tabular}{ll}
\hline Skort Kualitas Hidup & Nilai \\
\hline Mean & 102,6 \\
SD & 13,07 \\
Minimal-maksimal & $80-119$ \\
$95 \%$ CI & $95,09-110,19$ \\
\hline
\end{tabular}

Berdasarkan tabel 3 didapatkan bahwa rata rata kualitas hidup pasien HIV sesudah pemberian SEFT adalah 102,6 dengan standar deviasi 13,07.

\section{Analisa Bivariat}

Tabel. 4

Distribusi Rata Rata Kualitas Hidup Pasien HIV Sebelum dan Sesudah Tindakan SEFT

\begin{tabular}{lccccc}
\hline Variabel & Mean & SD & SE & P Value & N \\
\hline Skor Kualitas Hidup & & & & & \\
Sebelum & 97,07 & 10,292 & 2,751 & 0,011 & 14 \\
Sesudah & 102,64 & 13,071 & 3,49 & & \\
\hline
\end{tabular}

Berdasarkan tabel 4 dapat dilihat bahwa rata-rata skort kualitas hidup pasien HIV sebelum tindakan SEFT adalah 97,07 dengan standar deviasi 10,292. Sesudah dilakukan tindakan SEFT didapatkan rata-rata skort kualitas hidup 102,64 dengan standar deviasi 3,49. Hasil Uji statistic didapatkan nilai $p=0,011$ maka dapat disimpulkan ada perbedaan yang signifikan antara kualitas hidup pasien HIV sebelum dan sesudah tindakan SEFT. 


\section{PEMBAHASAN}

Hasil penelitian ini, didapatkan bahwa rata rata kualitas hidup pasien HIV sebelum pemberian SEFT adalah 97,07 , artinya kualitas hidup pasien HIV tersebut baik. Hasil Penelitian ini sejalan dengan beberapa penelitian yang menyatakan pada umumnya Kualitas Hidup pasien HIV setelah diberikan obat ARV baik (Kholifah, 2019; Avelina \& Idwan, 2019).

Kualitas hidup Pasien HIV yang baik ini berkaitan dengan tempat penelitian, dimana sampel penelitian ini diambil di yayasan taratak Jiwa hati yang merupakan salah satu yayasan pemerhati HIV, dimana pasien HIV itu sudah mendapatkan dukungan dari Teman Sesama penderita HIV. Dimana setiap bulannya diadakan kegiatan untuk meningkatkan kesehatan mereka.Selain itu, kualitas hidup Pasien baik juga dikarenakan memakan obat Anti Retro Viral setiap hari.

Kualitas Hidup Pasien Ini juga ada kaitannya dengan Karakteristik Responden, Dimana Pendidikan responden pada umumnya adalah tamatan sekolah menengah atas (SMA) sebanyak 78,5\%,sedangkan 14,3\% lagi berpendidikan sarjana dan 7,1\% tamatan Diploma 1. Hal ini sejalan dengan penelitian yang dilakukan Mariany (2019) terhadap 19 responden, paling banyak adalah responden dengan tingkat pendidikan SMA yaitu $75 \%$. Pendidikan merupakan factor yang dapat mempengaruhi pasien dalam menentukan pilihan pengobatan. Seseorang dengan pendidikan tinggi biasanya lebih memahami penyakit dan petunjuk yang diberikan dalam penggunaan obat yang diberikan. Status pendidikan juga mempengaruhi tingkat informasi yang didapat seseorang sehingga individu dengan pendidikan tinggi dapat memahami informasi lebih baik dibandingkan dengan individu dengan tahap pendidikan rendah .

Pendapat peneliti bahwa pendidikan sangat penting dalam proses penerimaan informasi kesehatan. Pasien HIV yang memiliki pendidikan tinggi memiliki kemampuan kognitif yang baik untuk menerima, mencari informasi tentang perawatan dirinya. Sehingga pasien dengan pendidikan tinggi memiliki kualitas hidup yang baik.

Selain tingkat pendidikan, menurut peneliti status perkawinan juga berhubungan dengan kualitas hidup Pasien HIV. Hasil penelitian menunjukkan separoh dari responden status perkawinannya adalah kawin, hal ini dikarenakan seseorangyang sudah menikah dan belum menikah/duda/janda mempunyai sumber koping yang adekuat, baik dari keluarga, pasangannya, dukungan sosial dan keluarga, dukungan darikonselor rumah sakityang memiliki peran dalam meningkatkan kepercayaan diri seseorang sehingga dapat lebih mengembangkan kopingyang adaptif terhadap stressor.

Dari hasil penelitian ini didapatkan bahwa pada umumnya responden $(64,3 \%)$ mengatakan status kesehatannya baik baik saja, (50\%) responden mengatakan status HIV nya tidak bergejala, hal ini juga mempengaruhi kualitas Hidup, dimana responden semuanya sedang meminum obat ARV yang berfungsi meningkatkan kesehatan pasien sehaingga secara tidak langsung dapat meningkatkan kualitas hidupnya .

Dari hasil penelitian ini, didapatkan responden berdasarkan pertama kali menderita HIV,mulai dari 2008 - 2019, tetapi Hampir separoh responden $(28,6 \%)$ pertama kali menderita HIV pada tahun 2018 dan 21,4 \% menderita HIV sejak 2019 ini. Dapat disimpulkan bahwa responden sudah menderita HIV lebih satu tahun, sehingga kualitas hidupnya membaik.

Hasil ini sesuai dengan penelitian Schulte et al., (2020) menunjukan bahwa pasien $H I V$ pada stadium lanjut memiliki kualitas hidup lebih tinggi. Pada tahap ini pasien pengguna ARV merasa obat-obatan telah menjadi bagian dari rutinitas sehari-hari. Hal ini senada dengan hasil penelitian oleh Ezeamama et al., (2019) menunjukan bahwa 
penggunaan obat-obatan ARV menunjukan kualitas hidup lebih baik dibandingkan dengan pasien yang tidak mengkonsumsi ARV. Kualitas hidup pasien yang mengalami stigma lebih rendah dibandingkan dengan kulaitas hidup pasien yang tidak mengalami stigma.

Penyakit HIV AIDS yang dialami oleh individu dalam kehidupannya akan membawa akibat baik secara fisik, mental, maupun kehidupan sosialnya. Dampak buruk pada aspek kesehatan fisik, psikologis, hubungan sosial, dan lingkungan akan menurunkan kualitas hidupnya. Secara fisik jika seorang penderita HIV yang tidak mendapat pengobatan, maka pada umumnya setelah 5 tahun penderita akan meninggal. Penyakit HIV AIDS juga memberikan dampak buruk lainnya secara sosial, diantaranya stigma bahkan dikucilkan oleh masyarakat. Menurunnya aktivitas sosial akan berdampak buruk pada kebermaknaan hidup dan menurunnya harga diri penderita HIV, hal tersebut akan berdampak negatif pada kualitas hidup.

Berdasarkan hasil penelitian didapatkan bahwa rata rata kualitas hidup pasien HIV sesudah pemberian SEFT adalah 102,6 mengalami kenaikan sedikit bila dibandingkan sebelumnya. Hal ini sejalan dengan penelitian Ardan (2020) hasil penelitiannya menunjukkan therapy SEFT dapat menurunkan tingkat depresi pasien HIV AIDS. Penelitian lain juga menjelaskan SEFT sudah digunakan sebagai terapi menurunkan depresi pada narapidana laki laki, sehingga dapat disimpulkan bahwa SEFT ini sudah banyak digunakan untuk mengatasi gangguan psikologis (Narendri, 2019).

Terapi SEFT dikembangkan dari Emotional Freedom Technique (EFT), oleh Gary Craig (USA), yang saat ini sangat populer di Amerika, Eropa, dan Australia sebagai solusi tercepat dan termudah untuk mengatasi berbagai masalah fisik, dan emosi, serta untuk meningkatkan performa kerja. Menurut Nurjanah (2019) SEFT sangat berpengaruh untuk mengurangi kecanduan merokok. SEFT juga terbukti berpengaruh terhadap penurunan tekanan darah systole dan diastole.

Terapi SEFT terdiri dari dua aspek, yaitu spiritual dan biologis. Menurut Farmawati (2019) Spiritualitas adalah bagaimana kita mendefinisikan diri sebagai individu dan mencari makna serta tujuan dalam kehidupan kita. Aspek spiritual terdiri dari dua langkah, yaitu Set-Up yang bertujuan untuk memastikan agar aliran energi tubuh kita terarahkan dengan tepat. Langkah ini dilakukan untuk menetralisir "psychological reversal" atau "perlawanan psikologis", dan berisi doa kepasrahan. Langkah kedua adalah Tune-In dengan cara merasakan rasa sakit yang kita alami, lalu mengarahkan pikiran kita ke tempat rasa sakit (Self-Hypnosis). Aspek kedua adalah aspek biologi, yang terdiri dari tapping atau ketukan ringan pada 18 titik energi tubuh (The Major Energy Meridians) yang akan menimbulkan potensial aksi. Ketukan yang dilakukan akan merangsang "electrically active cells" sebagai pusat aktif yang terdiri dari kumpulan sel aktif yang ada di permukaan tubuh. Tapping dalam SEFT akan menimbulkan hantaran rangsang berupa sinyal transduksi yang terjadi dalam proses biologik akibat rangsangan pada titik utama SEFT. Jalur meridian spesifik yang berkaitan dengan HIV adalah bagian yang sedang sakit.

Berdasarkan hasil penelitian ini dapat dilihat bahwa rata-rata skort kualitas hidup pasien HIV sebelum tindakan SEFT adalah 97,07 dengan standar deviasi 10,292. Sesudah dilakukan tindakan SEFT didapatkan rata-rata skort kualitas hidup 102,64 dengan standar deviasi 3,49 .Terlihat nilai mean perbedaan antara sebelum dan sesudah tindakan SEFT adalah 5,57 dengan standar deviasi 6,98. Hasil Uji statistic didapatkan nilai $\mathrm{p}=0,011$ maka dapat disimpulkan ada perbedaan yang signifikan antara kualitas hidup pasien HIV sebelum dan sesudah tindakan SEFT. 
Berdasarkan wawancara dengan responden setelah penelitian, didapatkan informasi bahwa tindakan SEFT ini sangat bermanfaat bagi pasien HIV diantaranya membantu untuk menghilangkan stress yang dialami . SEFT juga membantu menghilangkan keluhan fisik yang dirasakan pasien, dimana salah seorang pasien mengatakan setelah melakukan SEFT matanya yang sakit bisa sembuh dengan cepat. Selain itu hampir semua pasien mengatakan setelah melakukan tindakan SEFT ini badan menjadi lebih segar, stress hilang, tidur menjadi nyenyak.

Hal ini sesuai dengan penelitian yang dilakukan Arnata \& Lestari (2018) dimana terdapat peningkatan kualitas tidur lansia setelah dilakukan SEFT. Penelitian Desmaniarti \& Avianti (2017) hasil independent t-test menunjukkan bahwa SEFT bermakna menurunkan stres pasien kanker serviks dengan perbedaan rerata selisih pre-posttest sebesar 18,02, p-value 0,000 (95\% CI 14,117-21,882).

Walaupun demikian, hasil penelitian ini juga menemukan ada $7,1 \%$ responden yang skort kualitas hidupnya menjadi turun setelah dilakukan SEFT, tetapi responden mengungkapkan tindakan SEFT sangat bermanfaat baginya. Hal ini mungkin disebabkan karena pasien melaksanakan SEFT dalam keadaan tidak bisa berkonsentrasi penuh, dan kurangnya kepasrahan kepada Allah SWT, sehingga masih enggan mengungkapkan kesalahan yang selama ini diperbuatnya.

\section{SIMPULAN}

Ada perbedaan yang signifikan antara kualitas hidup pasien HIV sebelum dan sesudah tindakan SEFT SEFT dipilih untuk meningkatkan kualitas hidup karena SEFT berfokus pada peningkatan spiritual dari pasien. Spiritual dan kesehatan adalah dua hal yang berkaitan. Bukti-bukti ilmiah mengatakan bahwa pada penyakit yang umum sekalipun, kondisi pikiran, emosi, sikap, kesadaran, dan doa- doa yang dipanjatkan oleh atau untuk pasien sangat berpengaruh bagi kesembuhannya. Hal tersebut akan berdampak positif pada peningkatan kualitas hidup pasien.

\section{SARAN}

Diharapkan kepada perawat untuk memberikan penyuluhan kepada Pasien HIV AIDS untuk melakukan tindakan SEFT setiap hari. Disarankan kepada peneliti selanjutnya untuk melakukan penelitian lain tentang cara meningkatkan kualitas Hidup pasien HIV.

\section{DAFTAR PUSTAKA}

Aminuddin, M., Samsugito, I., Nopriyanto, D., \& Puspasari, R. (2019). Terapi Seft Menurunkan Intensitas Kebiasaan Merokok Di Kelurahan Sambutan Kota Samarinda. JPPM (Jurnal Pengabdian Dan Pemberdayaan Masyarakat), 3(2), 329. https://doi.org/10.30595/jppm.v3i2.3899

Andri, J., Ramon, A., Padila, P., Sartika, A., \& Putriana, E. (2020). Pengalaman Pasien ODHA dalam Adaptasi Fisiologis. Journal of Telenursing (JOTING), 2(2), 127141. https://doi.org/10.31539/joting.v2i2.1397

Arnata, A. P., \& Lestari, P. (2018). Pengaruh Terapi Spiritual Emosional Freedom Technique Terhadap Peningkatan Kualitas Tidur pada Lansia di Desa Gondoriyo Kecamatan Bergas Kabuapten Semarang. Indonesian Journal of Nursing Research, 1(1), 1-14. http://jurnal.unw.ac.id:1254/index.php/ijnr/article/view/3 
Avelina, Y., Idwan, I (2019). Hubungan antara Dukungan Keluarga dengan Kualitas Hidup Pasien Hiv/Aids yang Menjalani Terapi di Klinik Vct Sehati RSUD dr. T.C. Hillers Maumere. Prosiding Seminar Nasional 2018, 93-103. https://doi.org/10.32528/psn.v0i0.1735

Bach, D., Groesbeck, G., Stapleton, P., Sims, R., Blickheuser, K., \& Church, D. (2019). Clinical EFT (Emotional Freedom Techniques) Improves Multiple Physiological Markers of Health. Journal of Evidence-Based Integrative Medicine, 24, 1-12. https://doi.org/10.1177/2515690X18823691

Blanco, J. L., Ambrosioni, J., Garcia, F., Martínez, E., Soriano, A., Mallolas, J., \& Miro, J. M. (2020). COVID-19 in Patients with HIV: Clinical Case Series. The Lancet HIV , 7(5), e314-e316. https://doi.org/10.1016/S2352-3018(20)30111-9

Desmaniarti, D., \& Avianti, N. (2017). Spiritual Emotional Freedom Technique Decreasing Stress on Patients with Cervical Cancer. Jurnal NERS, 9(1), 91. https://doi.org/10.20473/jn.v9i1.3233

Dewi, I. P., \& Fitri, S. U. R. (2020). Pemanfaatan Seft sebagai Modalitas Therapy Community (TC) untuk Kesehatan Mental dan Spiritual Pecandu Napza. Jurnal Pengabdian Untukmu NegeRI, 48-94. https://doi.org/10.37859/jpumri.v4i1.1895

Ezeamama, A. E., Sikorskii, A., Bajwa, R. K., Tuke, R., Kyeyune, R. B., Fenton, J. I., Guwatudde, D., \& Fawzi, W. W. (2019). Evolution of Anemia Types during Antiretroviral Therapy-Implications for Treatment Outcomes and Quality of Life among Hiv-Infected Adults. Nutrients, 11(4), 1-16. https://doi.org/10.3390/nu11040755

Farmawati, C. (2019). Sufistic Therapy with Spiritual Emotional Freedom Technique (Seft) Method for Healing the Behavior of Drugs Addict. Jurnal THEOLOGIA, 30(1), 107. https://doi.org/10.21580/teo.2019.30.1.3393

Irmak Vural, P., \& Aslan, E. (2019). Emotional Freedom Techniques and Breathing Awareness to Reduce Childbirth Fear: A Randomized Controlled Study. Complementary Therapies in Clinical Practice, 35(February), 224-231. https://doi.org/10.1016/j.ctcp.2019.02.011

Kholifah, K. (2019). Hubungan Lama Terapi Antiretroviral (ARV) terhadap Kualitas Hidup Pasien Human Immunodeficiency Syndrome (HIV/AIDS). Universitas Islam Sultan Agung

Kusnanto, K., Pradanie, R., \& Karima, A. I. (2016). Spiritual Emotional Freedom Technique (SEFT) terhadap Kualitas Hidup Penderita Tuberkulosis Paru. Jurnal Keperawatan Padjadjaran, v4(n3), 213-224. https://doi.org/10.24198/jkp.v4n3.1

Narendri, N. I. (2019). Keefektifan Spiritual Emotional Freedom Technique (Seft) untuk Menurunkan Kecenderungan Depresi pada Narapidana Laki-Laki. Universitas Begeri Semarang. http://lib.unnes.ac.id/id/eprint/33639

Nicosia, G. J., Minewiser, L., \& Freger, A. (2019). World Trade Center: A Longitudinal Case Study for Treating Post Traumatic Stress Disorder with Emotional Freedom Technique and Eye Movement Desensitization and Reprocessing. Work, 63(2), 199-204. https://doi.org/10.3233/WOR-192921

Nurbani, N., Yuniar, L. (2020). Terapi S Pritual Emotional Fredoom Technique Mengurangi Fredoom Therapy Spritual Therapy Therapy Reduces Depression in Diabetes Millitus Patients. Jurnal Keperawatan Jiwa, 8(2), 129-138. DOI: https://doi.org/10.26714/jkj.8.2.2020.129-138 
Nurjana, D. S. (2019). Terapi Kecanduan Rokok dengan Menggunakan Metode Spiritual Emotional Freedom Technique (Seft). Syifa Al-Qulub, 3(2), 112-119. DOI: https://doi.org/10.15575/saq.v3i2.3536

Razavi, P., Hajifathalian, K., Saeidi, B., Esmaeeli Djavid, G., Rasoulinejad, M., Hajiabdolbaghi, M., Paydary, K., Kheirandish, P., Foroughi, M., Seyedalinaghi, S., Mohraz, M., \& McFarland, W. (2012). Quality of Life among Persons with HIV/AIDS in Iran: Internal Reliability and Validity of an International Instrument and Associated Factors. AIDS Research and Treatment, 2012. https://doi.org/10.1155/2012/849406

Schulte, A., Weber, I., Tiga-Loza, D. C., Amaya, L I. Y., Shepard, D. S., Tschampl, C. A., Undurraga, E. A., Martínez-Vega, R. A., Fischer, F., Chihu, L., \& RamosCastañeda, J. (2020). Health-Related Quality of Life after Dengue Fever, Morelos, Mexico, 2016-2017. Emerging Infectious Diseases, 26(4), 751-755. https://doi.org/10.3201/eid2604.190729

Stapleton, P., Buchan, C., Mitchell, I., McGrath, Y., Gorton, P., \& Carter, B. (2018). An Initial Investigation of Neural Changes in Overweight Adults with Food Cravings after Emotional Freedom Techniques. OBM Integrative and Complementary Medicine, 4(1), 1-1. https://doi.org/10.21926/obm.icm.1901010 